\title{
Assessing Students' Digital Literacy Skill in Senior High School Yogyakarta
}

\author{
Riki Perdana, Riwa Yani, Jumadi Jumadi, Dadan Rosana \\ Graduate School Program, Yogyakarta State University, Yogyakarta, Indonesia \\ e-mail: rikifisika95@gmail.com
}

\begin{abstract}
Digital literacy becomes a vital issue in this present era. The study aims at investigating students' digital literacy skills of students Grade X and XI in Senior High School in Yogyakarta. There were three steps to this research. First, we constructed the item format and aspect of digital literacy skills. Second, the administration of this research to 193 students of science class in Yogyakarta which were selected randomly. The last analysis data of students' digital literacy skills based on educational level. For the profile of students' digital, we used descriptive and quantitative statistics (frequency and percent). To determine the significant difference between the students' level, we also used an independent sample t-test. Result of this study showed that the students' digital literacy skill of all students was deficient level. Besides, there was a significant difference in students' digital literacy skills based on educational level. The conclusion was that students' digital literacy skill in Yogyakarta was deficient, and there must be an effort to force these skills. The recommendation for the future study is to develop a learning model that can enhance students' digital literacy skills. For the policymakers, learning based on digital literacy skills must be integrated into the curriculum. ICT learning should be taught to students in Indonesia, especially in Yogyakarta.
\end{abstract}

Keywords: Digital Literacy Skill

\section{Introduction}

The growth of digital culture in the twenty-first century has encouraged the use of digital resources and communication tools in school education (Kong, 2014), so students are asked to express their ideas in digital media (Chan, Churchill, \& Chiu, 2017). Besides, they must also be proficient at interacting with files include converting and creating graphics from one type to another and using web-based tools to complete sophisticated tasks (Frydenberg, 2015).

The role of digital technology in daily life has increased in over the past few decades (Bekker, Bakker, Douma, van der Poel, \& Scheltenaar, 2015). Nevertheless, many educational institutions have not fully embraced digital literacy as basic literacy equivalent to reading, writing, and counting (Coffin Murray \& Pérez, 2017). The adoption of digital literacy skills to improve quality is an essential problem for the digital learning environment (Techataweewan \& Prasertsin, 2018).

For education professionals, the implication of increasing student involvement with digital media is to help students develop knowledge, skills, and dispositions to live, contribute and develop in the 21st-century digital world (Redmond, 2015). The success of students has been linked to 'digital literacy' as citizens involved in building the nation in the future (Pangrazio, 2016).

It is difficult to give a precise definition of "digital literacy" because this term has been used for various meanings in the literature (Güneş \& Bahçivan, 2018). Digital literacy often seems to amount to a minimum of the skills that will allow users to operate effectively with software tools, or in carrying out basic information search tasks (Buckingham, 2015). Digital literacy has several elements such as critical thinking skills, creativity, building and evaluating information, and using digital media effectively, and it can be developed as a result of students' digital writing (AI-Qallaf \& Al-Mutairi, 2016).

Digital literacy for learning is more than just knowing how to operate technology but also having the right information management and critical thinking skills, as well as appropriate online behavior (Tang \& Chaw, 2016). Besides, digital literacy not only understands how tools work but also why these tools are useful in the real world and when to use them (Alexander, B., Adams Becker, S., Cummins, 2016). These skills represent a set of discrete abilities or 
behaviors expressed by users of digital information systems, often in the process of investigation (Meyers, Erickson, \& Small, 2013) in other words, it related to skills and abilities utilizing ICT (Prior, Mazanov, Meacheam, Heaslip, \& Hanson, 2016).

Digital literacy enables one's participation in social networks to create and share knowledge and supports a variety of professional computing skills (Josie et al., 2018). The conceptualization of digital literacy as cultural competency, integrating aspects such as necessary technical skills, analyzing the media as an object itself, being critical of content and technology, and obtaining learning strategies for finding and utilizing information and learning for learning (Bjørgen \& Erstad, 2015). So, the digital environment that develops as an educational tool requires research on learners' digital literacy (Greene, Yu, \& Copeland, 2014).

There are many digital literacy components proposed by experts. Alkali \& AmichaiHamburger (2004) state five primary skills of digital Literacy: (1) photo-visual skills (reading graphic displays), (2) re-productive skills (utilizing digital devices to make new and meaningful findings from pre-existing material), (3) branching skills (building knowledge from non-linear, hypertextual, and navigation), (4) information skills (evaluating the quality and validity of information), and (5) social-emotional skills (understanding "rules" that apply in the world virtually and apply this understanding in online cyber communication).

Bawden (2008) proposes four core digital literacy competencies are: (1) internet search, (2) hypertext navigation, (3) knowledge assembly, and (4) content evaluation. Karpati (2011) states that for future computer users and ICT professionals, the essential component of digital literacy is: accessing, managing, evaluating, integrating, making, and communicating information individually or collaboratively on networks, supported by computers, and webbased environments for study, work, or recreation.

Digital literacy is produced from three dimensions, which intersect, namely (1) technical (2) cognitive and (3) social-emotional dimensions of digital literacy ( $\mathrm{Ng}, 2012)$. Hatlevik, O. E., \& Christophersen (2013) propose digital literacy competencies include skills in using technology, utilizing technology to the process, obtain, evaluate information, produce, and communicate information. Bollard, Kerry, Whitney, \& Fidock (2014) measure digital literacy skills with aspects of digital device ownership, social use and work of digital devices, and attitudes towards the use of digital technology in training.

Kazakoff (2015) states that there are six components of digital literacy: (1) understanding and utilizing digital devices; (2) understand navigation tools in digital devices; (3) Able to think critically and solve digital problems; (4) Active in learning and able to cooperate in creative design through digital devices. Reynolds (2016) offers a new conceptualized modular framework for digital literacy that defines this concept as "task constructivist digital literacy," which consists of 6 practice domains based on social constructivism and constructivism: Create, Manage, Publish, Promote, Research, and Surf.

Josie et al., (2018) identified five digital literacy disciplines. The first is information literacy, including the ability to search, retrieve, manipulate, evaluate, synthesize, and create digital content. The second is computer literacy, including the ability to operate digital hardware and software to be able to understand how to use various forms of tools is essential to understand technology. The third is media literacy, including the ability to interact with text, sound, images, videos, and social media. The forth is communication literacy, including communication skills in traditional and innovative media. The last is technological literacy, including the ability to adopt various technologies for specific life situations.

There are various researches on digital literacy. Prabhu (2010) focuses on tests of critical thinking certification formulated by Educational Testing Service and Certiport that provide basic guidelines for digital literacy by measuring critical thinking skills in technologysupported environments. Machala \& Orešković (2014) measured librarians' information and digital literacy activities at the national lifelong learning portal and tested the application of API Experience (xAPI) as information and digital literacy assessment instruments.

Greene et al. (2014) examined how critical aspects of digital literacy are related to student learning outcomes when using the Internet to investigate everyday health and public science topics. Lee (2014) focuses on measuring significant differences between before and after digital literacy education through tests and surveys before and after treatment is given. 
Literat (2014) assessed the psychometric properties of the newly tested self-report assessment tool for media literacy, based on twelve new media literacy skills (NML) developed by (Jenkin, Clinton, Purushotma, Robison, \& Weigel, 2006).

Ainley, Schulz, \& Fraillon (2016) review the definitions of digital literacy and ICT that have been adopted in cross-national studies, investigate approaches to digital literacy and ICT assessment that have been used in the study and articulate criteria that should guide the development of a global measure of literacy skills digital and ICT. Siddiq, Gochyyev, \& Wilson (2017) develop test efforts to measure students' ability to handle digital information, to communicate, and collaborate during problem-solving. Other research investigates digital literacy among junior high school students to compare perceptions of participants' digital literacy competencies and their actual performance in relevant digital tasks (Porat, Blau, \& Barak, 2018).

In Indonesia, especially the province of Yogyakarta, research on students' digital literacy skills is still rare. In fact, as one of the major cities in Indonesia, this province must have valid data regarding digital literacy skills. As a student city, Yogyakarta must be a role model for other cities in following the current development of education in the 21st century. In this study, we focused on measuring students' digital literacy skills and proving whether there were differences in student skills based on education levels. The research questions in this question are: (1) What is the level of students' digital literacy skills in Yogyakarta? (2) Are there significant differences in the level of digital literacy skills based on educational levels?

\section{Method}

The first stage in measuring digital literacy skill of the students was defining what the definition of digital literacy skill is and selecting the aspect of digital literacy skill that should be targeted in this research. As described in the introduction, one of the difficulties in assessing digital literacy skills is the widespread disagreement among researchers and educators about what aspects can represent students' digital literacy skills. Therefore, we initially reviewed available research on standardized digital literacy by considering several things. First, we aim to identify the critical skills of digital literacy that are commonly developed. These critical skills are the focus of our tests, and thus we can build the right kind of digital literacy skills. Second, we determine the aspects studied by reflecting the existing digital literacy skills test so that the selected aspects directly intersect with digital literacy skills. All components reviewed based on (a) are following clear definition/concept of digital literacy, (b) whether the targeted digital literacy skills are general, and (c) whether they represent digital literacy skills as a whole. Based on the results of the review, the components of digital literacy skills examined in this study are as in Table 1.

Table 1. The aspect of Digital Literacy Skill

\begin{tabular}{|c|c|}
\hline The aspect of Digital Literacy & Item \\
\hline $\begin{array}{l}\text { Knowledge Assembly } \\
\text { Content evaluation } \\
\text { Internet searching } \\
\text { Hyper textual navigation }\end{array}$ & $\begin{array}{c}\text { Two items } \\
\text { Three items } \\
\text { Two items } \\
\text { Three items }\end{array}$ \\
\hline 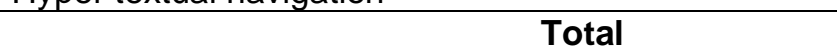 & 10 Items \\
\hline
\end{tabular}

The test was administered to students grade $X(N=96)$ and grade $X I$ (97) in senior high school in Yogyakarta, was selected randomly. The students did not participate in any of the previous pilot studies and were enrolled in the digital literacy aspect. The participant consisted of 197 students between the ages of $13-17$ years. Before the administration, the participants were given the initial instruction regarding the goal of the test. They were also given general direction about how to respond to the items and asked to take the test seriously. The test was administered similarly to Tiruneh, De Cock, Weldeslassie, Elen, \& Janssen (2017), where hold in a controlled classroom setting and great caution was made for all students to hand in the test so that test questions would not circulate. The participants were 
not given a time limit to answer the questions given. However, we conveyed the possibility of taking about 60 minutes to complete all the questions. About $90 \%$ of students can complete within 50 minutes, and the rest is completed in 60 minutes.

We used SPSS version 16 to analyze data. For the profile of the students' digital literacy skills, the descriptive and quantitative statistic was used, including frequency and percent. The independent sample t-test was used to determine the significant difference in the level of digital literacy skills of students in grade X and grade XI.

\section{Result and Discussion}

Based on the test, students were given ten questions according to the aspect of digital literacy skills. The result has reveled in Table 2. The table shows the level of their answer in the test.

Table 2. The Level of Digital Literacy Skill of The Students

\begin{tabular}{lccc}
\hline \multirow{2}{*}{ The aspect of Digital Literacy } & \multicolumn{2}{c}{ Students on X Grade } & \multirow{2}{*}{ Description } \\
\cline { 2 - 3 } & Mean & SD & \\
\hline Knowledge Assembly & 1.02 & 0.32 & Very low \\
Content evaluation & 1.51 & 0.95 & Very low \\
Internet searching & 1.56 & 1.56 & Very low \\
Hyper textual navigation & 1.06 & 0.60 & Very low \\
\hline \multicolumn{1}{c}{ Overall } & $\mathbf{1 . 2 7 5}$ & $\mathbf{0 . 7 0}$ & Very low \\
\hline
\end{tabular}

Among the ten questions that administrated on the students' Grade $X$, answers of the students in internet searching show the highest mean of 1.56 (very low). Moreover, the answers in knowledge assembly present the lowest mean of 1.02 (very low). It can be gleaned from the table that students on Grade $X$ have deficient level digital literacy skills (mean = $1.275, S D=0.70$ ). Table 3 shows the frequency and percent of students by each level of digital literacy skill.

Table 3. Frequency of Students' Digital Literacy Skill on Grade X

\begin{tabular}{lccc}
\hline & Level & Frequency & $\%$ \\
\hline Very low & 87 & $89.7 \%$ \\
Low & 9 & $9.27 \%$ \\
Average & 1 & $1.03 \%$ \\
High & 0 & 0 \\
Very high & 0 & 0 \\
\hline \multicolumn{2}{r}{ Overall } & \multicolumn{2}{c}{ Mean $=\mathbf{1 . 2 7 5 ;}$ SD $=\mathbf{0 . 0 0}$} \\
\hline
\end{tabular}

According Table 3, the students on Grade X have very low digital literacy skills (mean $=1.275, \mathrm{SD}=0.00)$. Most $(89.7 \%$ of total 97 students $)$ of the students have a deficient level of digital literacy skill while few (9.27\%) students have a low level of digital literacy skill, and only $1.03 \%$ of the students have an average level of digital literacy skill.

Based on the test, students on grade $\mathrm{XI}$ also were given ten questions according to the aspect of digital literacy skills. The result revels in Table 4. The table shows the level of their answer in the test. 
Table 4. The Level of Digital Literacy Skill of The Students

\begin{tabular}{lccc}
\hline \multirow{2}{*}{ The aspect of Digital Literacy } & \multicolumn{2}{c}{ Students on XI Grade } & \multirow{2}{*}{ Description } \\
\cline { 2 - 3 } & Mean & SD & Very low \\
\hline Knowledge Assembly & 0.73 & 0.21 & Very low \\
Content evaluation & 2.10 & 1.27 & Very low \\
Internet searching & 2.52 & 1.33 & Very low \\
Hyper textual navigation & 1.44 & 0.94 & Very low \\
\hline \multicolumn{1}{c}{ Overall } & $\mathbf{1 . 7 1}$ & $\mathbf{0 . 7 1}$ & \\
\hline
\end{tabular}

Among the ten questions that administrated on the students' Grade XI, answers of the students in internet searching also show the highest mean of 2.52 (very low). Moreover, the answers in knowledge assembly also present the lowest mean of 0.73 (very low). It can be gleaned from the table that students on Grade XI have deficient level digital literacy skills (mean $=1.71, \mathrm{SD}=0.71$ ). Table 5 shows the frequency and percent of students by each level of digital literacy skill.

Table 5. Frequency of Students Digital Literacy Skill on Grade XI

\begin{tabular}{lccc}
\hline & Level & Frequency & $\%$ \\
\hline Very low & 77 & 80.2 \\
Low & 8 & 8.3 \\
Average & 11 & 11.5 \\
High & 0 & 0 \\
Very high & 0 & 0 \\
\hline \multicolumn{2}{r}{ Overall } & \multicolumn{2}{c}{ Mean $=\mathbf{1 . 7 1 ;}$ SD $=\mathbf{0 . 9 8}$} \\
\hline
\end{tabular}

According Table 5, the students on Grade XI have very low digital literacy skills (mean $=1.71, \mathrm{SD}=0.98)$. Most $(80.2 \%$ of total 96 students $)$ of the students have a deficient level of digital literacy skill while few (8.3\%) students have a low level of digital literacy skill, and $11.5 \%$ of the students have an average level of digital literacy skill.

Data analysis of the students' answers from a digital literacy test. Using the average score of students on Grade X and XI, the significant difference in their level of students' digital literacy skills was determined using an independent sample t-test. The result is shown in Table 6.

Table 6. Independent Sample t-test

\begin{tabular}{cccccccc}
\hline Groups & N & Mean & SD & t & dF & P & Description \\
\hline Grade X & 97 & 1.27 & 0.82 & -4.204 & 191 & 0.000 & \multirow{2}{*}{ Significant } \\
Grade XI & 96 & 1.71 & 0.61 & & &
\end{tabular}

Based on Table 6 , the level of digital literacy skill of students in grade $X$ is significantly different $(t=4.204, P<0.005)$ from the students in Grade XI. The students in grade XI mean (1.71) difference of 0.44 over students in grade $X(1.27)$ indicates that the level of students' digital literacy skill in the grade $\mathrm{XI}$ is better than in the grade $\mathrm{X}$. The higher digital literacy skill of the grade $\mathrm{XI}$ is attributed to the learning they have during the teaching-learning process. But, unfortunately, these skills also in the deficient level of digital literacy aspect.

Based on the results of the study, we know that all aspects of students' digital literacy skills are still very low for both students of class X and class XI. The order of aspects of students' digital literacy skills based on the highest to lowest average is internet searching, content creation, hypertextual navigation, and knowledge assembly.

The aspect of internet searching is the highest value aspect in both classes (mean of grade $X=1.56$, mean of grade $X I=2.52$ ) even though it is still at a deficient level. It is similar to (Tarimo \& Kavishe, 2017), who argue that the majority of internet users in secondary schools do not have the right search skills to access information using the Internet. The reason is the lack of training and skills in internet search strategies (Chirwa, 2018). It is because 
students usually do not have enough skills to appraise the information on the internet appropriately (Chiu, Liang, \& Tsai, 2016). This deficient level can also be caused by English language skills, where those who are proficient in English are better at searching for information using the internet (Shirazi, Heidari, Fard, \& Ghodsbin, 2019).

The second aspect of digital literacy skill in this study is content creation (mean of grade $X=1.51$, mean of grade $X I=2.10$ ). Students' skills in this aspect are also at a deficient level, even though this aspect provides opportunities for students to integrate and reflect on media experience in everyday life (Costa, Tyner, Henriques, \& Sousa, 2018). It can be caused because they do not make great efforts on the sub-aspects of content creation, such as networking with other content creators and their offline presence (Törhönen, Sjöblom, \& Hamari, 2018). Besides, they may not be able to use digital devices optimally to generate ideas or develop a new method. One of the conceptual definition of content creation is to use new ways of doing things (van Laar, van Deursen, van Dijk, \& de Haan, 2017).

Hyper textual navigation is one of the problematic aspects of digital literacy skill, which deficient level in this study (mean of grade $\mathrm{X}=$, mean of grade $\mathrm{XI}=$ ). One of the causes of students' digital literacy skills that are still very low in this aspect is that students have difficulty using computer equipment and software in selecting and reading information. It is similar to (Cordeiro, de Abreu, \& Estadieu, 2017), that based on the type of interactivity, hypertextual navigation skills describe interactive pieces in which users must use computer equipment and software to make reading choices in the database. Also, students may not often interact with the media to make reading choices in the database user interface technology as a constructor of customized and individualized data sets. Meanwhile, interaction with the media in making choices is also a sub-aspect of hypertextual navigation (Tunalı, 2016).

\section{Conclusion}

Based on the results and discussion, students' digital literacy skills are at a deficient level. The order of skills of the lowest to highest students are knowledge assembly, hypertextual navigation, content creation, and internet searching. It shows that knowledge assembly is the most challenging aspect of students' digital literacy skills, and internet searching is a natural aspect. Nonetheless, students' digital literacy skills in Yogyakarta are still deficient.

There is a significant difference between the digital literacy skills of class $X$ students and class XI. In other words, digital literacy skills are also influenced by the level of education. These findings prove that digital literacy-based learning is still very much needed by students. For the teachers, the learning process should always involve digital devices. Because learning with digital devices can improve students' digital literacy skills.

For the policymakers, digital literacy-based learning processes should again be integrated with the current curriculum. Besides, digital literacy learning is organized differently at each level of education. It is because digital literacy skills possessed by students differ based on the level of education. This level of different digital literacy skills requires different subject matter at each level of the curriculum.

Recommendations for further research, researchers should start learning models that are specifically for improving students' digital literacy skills. Besides, further research is needed with other aspects of student digital literacy skills, so that it can add to the information about the level of student digital literacy skills. Other studies can also focus on the leading causes of why students' digital literacy skills are still deficient. It can be a basic guideline for further research to address the problems of students' digital literacy skills.

\section{References}

Ainley, J., Schulz, W., \& Fraillon, J. (2016). A global measure of digital and ICT literacy skills. Global Education Monitoring Report, Education for People and Planet: Creating Sustainable Futures for All.

Al-Qallaf, C. L., \& Al-Mutairi, A. S. R. (2016). Digital literacy and digital content support learning. The Electronic Library. https://doi.org/10.1108/el-05-2015-0076

Alexander, B., Adams Becker, S., Cummins, M. (2016). Digital Literacy. An NMC Horizon 


\section{Project Strategic Brief. Scientific American.}

https://doi.org/10.1038/scientificamerican0995-190

Alkali, Y. E. \& Amichai-Hamburger, Y. (2004). Experiments in Digital Literacy. CyberPsychology \& Behavior. https://doi.org/10.1089/cpb.2004.7.421

Bawden, D. (2008). Origins and concepts of digital literacy. In: Lankshear C and Knobel M Digital Literacies: Concepts, Policies, and Practices. New York: Peter Lang.

Bekker, T., Bakker, S., Douma, I., van der Poel, J., \& Scheltenaar, K. (2015). Teaching children digital literacy through design-based learning with digital toolkits in schools. International Journal of Child-Computer Interaction. https://doi.org/10.1016/j.ijcci.2015.12.001

Bjørgen, A. M., \& Erstad, O. (2015). The connected child: tracing digital literacy from school to leisure. Pedagogies. https://doi.org/10.1080/1554480X.2014.977290

Bollard, L. M., Kerry, J. T., Whitney, S. J., \& Fidock, J. J. T. (2014). Digital literacy in the Australian and New Zealand Defence Forces: Current levels and implications. In SimTecT.

Buckingham, D. (2015). Defining digital literacy: What do young people need to know about digital media? Nordic Journal of Digital Literacy.

Chan, B. S. K., Churchill, D., \& Chiu, T. K. F. (2017). Digital Literacy Learning In Higher Education Through Digital Storytelling Approach. Journal of International Education Research (JIER). https://doi.org/10.19030/jier.v13i1.9907

Chirwa, M. (2018). Access and use of internet in teaching and learning at two selected teachers' colleges in Tanzania. International Journal of Education and Development using Information and Communication Technology (IJEDICT).

Chiu, Y. L., Liang, J. C., \& Tsai, C. C. (2016). Exploring the roles of education and Internet search experience in students' Internet-specific epistemic beliefs. Computers in Human Behavior. https://doi.org/10.1016/j.chb.2016.03.091

Coffin Murray, M., \& Pérez, J. (2017). Unraveling the Digital Literacy Paradox: How Higher Education Fails at the Fourth Literacy. Issues in Informing Science and Information Technology. https://doi.org/10.28945/1982

Cordeiro, J., de Abreu, F. M., \& Estadieu, G. (2017). Audience Participation in Interactive Art Systems. In Proceedings of ARTECH 2017. Macau, China. https://doi.org/10.1145/3106548.3106595

Costa, C., Tyner, K., Henriques, S., \& Sousa, C. (2018). Game Creation in Youth Media and Information Literacy Education. International Journal of Game-Based Learning. https://doi.org/10.4018/ijgbl.2018040101

Frydenberg, M. (2015). Achieving digital literacy through game development: an authentic learning experience. Interactive Technology and Smart Education. https://doi.org/10.1108/ITSE-08-2015-0022

Greene, J. A., Yu, S. B., \& Copeland, D. Z. (2014). Measuring critical components of digital literacy and their relationships with learning. Computers and Education. https://doi.org/10.1016/j.compedu.2014.03.008

Güneş, E., \& Bahçivan, E. (2018). A mixed research-based model for pre-service science teachers' digital literacy: Responses to "which beliefs" and "how and why they interact" questions. Computers and Education. https://doi.org/10.1016/j.compedu.2017.11.012

Hatlevik, O. E., \& Christophersen, K.-A. (2013). Digital competence at the beginning of upper secondary school: Identifying factors explaining digital inclusion. Computers \& Education, 63, 240-247. https://doi.org/:10.1016/j.compedu.2012.11.015

Jenkin, H., Clinton, K., Purushotma, R., Robison, A., \& Weigel, M. (2006). Confronting the Challenges of Participatory Culture: Media Education for the 21st Century. Retrieved from https://www.macfound.org/media/article_pdfs/JENKINS_WHITE_PAPER.PDF

Josie, J., Fang, C., Chetty, K., Qigui, L., Gcora, N., \& Wenwei, L. (2018). Bridging the digital divide: measuring digital literacy. Economics: The Open-Access, Open-Assessment EJournal. https://doi.org/10.5018/economics-ejournal.ja.2018-23

Karpati, A. (2011). Digital Literacy in Education. Moscow: UNESCO Institute.

Kazakoff, E. R. (2015). Technology-based literacies for young children: Digital literacy through 
learning to code. In Young Children and Families in the Information Age: Applications of Technology in Early Childhood. https://doi.org/10.1007/978-94-017-9184-7_3

Kong, S. C. (2014). Developing information literacy and critical thinking skills through domain knowledge learning in digital classrooms: An experience of practicing flipped classroom strategy. Computers and Education. https://doi.org/10.1016/j.compedu.2014.05.009

Lee, S.-H. (2014). Digital Literacy Education for the Development of Digital Literacy. International Journal of Digital Literacy and Digital Competence. https://doi.org/10.4018/ijdldc.2014070103

Literat, I. (2014). Measuring New Media Literacies: Towards the Development of a Comprehensive Assessment Tool. Journal of Media Literacy Education.

Machala, D., \& Orešković, M. (2014). Measuring Information and Digital Literacy Activities through Learning Record Store Repository of the National Training Centre for Continuing Education for Librarians in Croatia. https://doi.org/10.1007/978-3-319-14136-7_61.

Meyers, E. M., Erickson, I., \& Small, R. V. (2013). Digital literacy and informal learning environments: An introduction. Learning, Media, and Technology. https://doi.org/10.1080/17439884.2013.783597

$\mathrm{Ng}, \mathrm{W}$. (2012). Can we teach digital natives digital literacy? Computers and Education. https://doi.org/10.1016/j.compedu.2012.04.016

Pangrazio, L. (2016). Reconceptualizing critical digital literacy. Discourse. https://doi.org/10.1080/01596306.2014.942836

Porat, E., Blau, I., \& Barak, A. (2018). Measuring digital literacies: Junior high-school students' perceived competencies versus actual performance. Computers and Education. https://doi.org/10.1016/j.compedu.2018.06.030

Prabhu, M. T. (2010). New test measures students' digital literacy skills. ESchool News.

Prior, D. D., Mazanov, J., Meacheam, D., Heaslip, G., \& Hanson, J. (2016). Attitude, digital literacy, and self-efficacy: Flow-on effects for online learning behavior. Internet and Higher Education. https://doi.org/10.1016/j.iheduc.2016.01.001

Redmond, T. (2015). Media Literacy Is Common Sense: Bridging Common Core Standards with the Media Experiences of Digital Learners. Middle School Journal. https://doi.org/10.1080/00940771.2015.11461910

Reynolds, R. (2016). Defining, designing for, and measuring "social constructivist digital literacy" development in learners: a proposed framework. Educational Technology Research and Development. https://doi.org/10.1007/s11423-015-9423-4

Shirazi, F., Heidari, S., Fard, S. J., \& Ghodsbin, F. (2019). Pattern of internet use by Iranian nursing students: facilitators and barriers. Investigación y Educación En Enfermería, $37(2)$.

Siddiq, F., Gochyyev, P., \& Wilson, M. (2017). Learning in Digital Networks - ICT literacy: A novel assessment of students' 21st-century skills. Computers and Education. https://doi.org/10.1016/j.compedu.2017.01.014

Tang, C. M., \& Chaw, L. Y. (2016). Digital literacy: A prerequisite for effective learning in a blended learning environment? Electronic Journal of E-Learning.

Tarimo, R., \& Kavishe, G. (2017). Internet access and usage by secondary school students in Morogoro Municipality, Tanzania. International Journal of Education and Development Using Information and Communication Technology.

Techataweewan, W., \& Prasertsin, U. (2018). Development of digital literacy indicators for Thai undergraduate students using mixed-method research. Kasetsart Journal of Social Sciences. https://doi.org/10.1016/j.kjss.2017.07.001

Tiruneh, D. T., De Cock, M., Weldeslassie, A. G., Elen, J., \& Janssen, R. (2017). Measuring Critical Thinking in Physics: Development and Validation of a Critical Thinking Test in Electricity and Magnetism. International Journal of Science and Mathematics Education. https://doi.org/10.1007/s10763-016-9723-0

Törhönen, M., Sjöblom, M., \& Hamari, J. (2018). Likes and views: Investigating internet video content creators perceptions of popularity. In CEUR Workshop Proceedings.

Tunalı, E. (2016). Resonant field: a critical analysis of user interface design in digital media. Bliken: Bilkent University. 
Van Laar, E., van Deursen, A. J. A. M., van Dijk, J. A. G. M., \& de Haan, J. (2017). The relation between 21st-century skills and digital skills: A systematic literature review. Computers in Human Behavior. https://doi.org/10.1016/j.chb.2017.03.010 